\title{
Ocean governance: A first step
}

AUTHOR:

Jan Glazewski ${ }^{1}$

\section{AFFILIATION:}

IInstitute of Marine \&

Environmental Law, Marine Research Institute (MA-RE), University of Cape Town, Cape Town, South Africa

\section{CORRESPONDENCE TO:}

Jan Glazewski

\section{EMAIL:}

Jan.Glazewski@uct.ac.za

\section{POSTAL ADDRESS:}

Institute of Marine \&

Environmental Law, Marine

Research Institute (MA-RE),

University of Cape Town,

Private Bag, Rondebosch 7701,

South Africa

\section{KEYWORDS:}

Green Paper; environmental management; ocean governance; South Africa; Department of Environmental Affairs

\section{HOW TO CITE:}

Glazewski J. Ocean governance: A first step. S Afr J Sci. 2013;109(3/4), Art. \#a011, 2 pages. http://dx.doi.org/10.1590/ sajs.2013/a011

(C) 2013. The Authors

Published under a Creative

Commons Attribution Licence.
The publication of a Green Paper on the 'National Environmental Management of the Ocean' in the Government Gazette on the last day of October 2012 and inviting comment by mid-January 2013 is significant. A Green Paper is a discussion document that invites comment from interested parties and is generally followed by a White Paper. The process provides a vital opportunity for the scientific community, in particular, to make a contribution to the management of ocean affairs. The eventual publication of the White Paper will reflect government policy on ocean governance and affairs. The process may or may not culminate in new legislation.

With the adoption of the 1982 United Nations Convention on Law of the Sea, which has been ratified by South Africa and which, among other things, grants coastal states jurisdiction up to an extent of 200 nautical miles (the Exclusive Economic Zone or EEZ), the publication of the over 80-page Green Paper on 'environmental management of the ocean' is welcome, significant and long overdue. It commences by acknowledging that South Africa occupies a unique position, being located at the interface of the Indian and Atlantic Oceans with ready access to the vast Southern Ocean, including enjoying sovereignty over the Prince Edward Islands. In so doing, the document points out that the area over which South Africa enjoys jurisdiction has been increased threefold since the advent of internationally recognised 200 nautical mile EEZs.

The Green Paper would have been better titled a 'Green Paper on Ocean Governance' rather than 'Environmental Management of the Ocean' in my view. The word 'governance' is more inclusive of the entire spectrum of government stakeholders in South African waters rather than only the Department of Environmental Affairs (DEA), which is driving this particular initiative. Moreover, it is arguable that it is not the marine environment that has to be 'managed' but rather the people and legal personae who use ocean space and extract its abundant resources that need management. For these reasons, I suggest that the process rather be titled 'Green/White Paper on South Africa's Ocean Governance'.

The central thrust of the discussion document is its focus on 'ocean environmental information' (Objective 1) as well as 'ocean environmental knowledge' (Objective 2) with the overall purpose of ensuring better decision-making to ensure sustainable 'environmental management of South Africa's ocean' (Objective 3 ) and to ensure 'ocean environmental integrity' (Objective 4). While the first two objectives may be laudable, they are in my view more in the nature of a vision and are too narrowly focused, as elaborated below. The third and fourth objectives, while also laudable, need to be fleshed out in the form of a strategy as to how these rather vague exhortations are going to be achieved. Related to these weaknesses is the fact that the document does not put any recommendations on the table for consideration and debate.

There is little indication in the Green Paper of an extensive public participation process having been carried out, both within government departments as well as with non-governmental organisations involved in marine matters. This current process is in sharp contrast to the related integrated coastal area management process, which took place just over a decade ago over a period of over 10 years. In that case, there was an extensive public participation process which, amongst other things, entailed the publications of Our Coast Our Future: Coastal Policy Green Paper: Towards Sustainable Coastal Development in South Africa (Department of Environmental Affairs and Tourism, September 1998) and the White Paper for Sustainable Coastal Development in South Africa (Department of Environmental Affairs and Tourism, Coastal Management Policy Programme April 2000) and culminated in the repeal and replacement of the outdated Sea Shore Act 1935 with the National Environmental Management: Integrated Coastal Area Management Act 24 of 2008 (NEM:ICMA). While that process was arguably perhaps too long and protracted, it is not altogether clear what end result is envisaged for the current process. It is possible that an ocean governance act is envisaged but, if so, the relationship between such an act and the NEM:ICMA will have to be clarified.

Related to this issue is the fact that South Africa's marine environment involves a broad spectrum of users and a rich array of both living and non-living resources, as well as unique marine biodiversity. The Green Paper emphasises the DEA's custodial role in the ocean space while seemingly paying scant attention to past and ongoing activities and other key stakeholders. Apart from the DEA, which is driving this process, a wide array of national government departments have a direct or indirect interest in South Africa's ocean space and resources: the Department of Agriculture, Forestry and Fisheries (marine fisheries); the Department of Arts, Culture and Heritage (historical wrecks); the Department of Communications (undersea communication cables); the Department of Defence (Navy); the Department of Energy (oil and gas, coastal nuclear facilities, renewable energy); the Department of International Relations (representation at international marine fora, including climate change negotiations); the Department of Minerals (offshore minerals, oil and gas); the Department of Science and Technology (scientific research); the Department of Transport (ports, marine transport including shipping, marine pollution from shipping activities); and the Department of Water Affairs (land-based sources of marine pollution). Apart from these national departments, the four coastal provinces (Northern Cape, Western Cape, Eastern Cape and KwaZulu-Natal), as well as coastal municipalities, have a direct interest in marine issues.

In addition to government agencies, a number of parastatal organisations have an interest. These include the Council for Scientific and Industrial Research, Eskom, the National Energy Regulator of South Africa, the Nuclear Energy Corporation of South Africa, PetroSA (Mossgas), the South African Maritime Safety Authority, the South African Weather Service, Telkom and the Transnet National Ports Authority. Finally, non-governmental organisations such as the Endangered Wildlife Trust, Worldwide Fund for Nature (SA), the South African Institute of Foreign Affairs and the Wildlife and Environment Society of South Africa also have an interest. Unless these various governmental 
and non-governmental agencies are thoroughly consulted and their views taken into account, the process is likely to flounder.

When Mr Zuma became President in 2009 a number of national government ministries were re-arranged and re-structured. As a result, fisheries management no longer falls under the purview of the DEA but now resides in the Ministry of Agriculture, Forestry and Fisheries. The Green Paper makes no mention of this fact. There is a need for a debate on whether fisheries management should revert to the Department of Environmental Affairs, which has as its mandate the sustainable utilisation of natural resources, or whether it should remain with agriculture and forestry, being a form of husbandry. The recent spat about the Minister of Agriculture, Forestry and Fisheries disregarding sound scientific advice on rock lobster quotas in favour of political expediency bears this point out. This matter needs more extensive airing.

Similarly, in regard to the issue of marine pollution, the current division of marine pollution control functions among the Department of Transport, the South African Maritime Safety Authority and the DEA needs consideration. In addition to oil spills, there are other pollution issues unique to the marine environment, such as adsorption and transport of persistent organic pollutants on marine plastic debris, bio-accumulation of toxic trace metals and other elements in marine food webs, local eutrophication of coastal marine habitats and outbreaks of harmful algal blooms, e.g. red tides.

The question of implementation and enforcement of marine environmental laws is a particularly vital aspect that requires cross-departmental involvement and to which inadequate attention is given in the Green Paper. There should be, among other things, a specific discussion on the implementation and enforcement of South Africa's marine environmental laws. These include regulating South Africa's fisheries interests (including coastal communities' historical fishing interests), offshore prospecting and mining, monitoring and combating marine pollution, and conserving cultural heritage such as historic wrecks. The potential role of the Navy and private salvage operators is specifically relevant in this regard but the document omits to raise these questions.

In conclusion, while the initiative is welcomed it is not clear what the ultimate objective of this Green Paper is. Is it to improve cooperative governance in the ocean space, to draft new legislation in the form of an ocean governance act, or both? There is a need for a chief agency involved in ocean affairs to play a median role between long-term sustainable economic development and custodianship or stewardship in managing South Africa's oceans (we need to find the 'Golden Mean'). In the preamble to the White Paper there is a need to recognise this tension between conservation and exploitation. Related to this is the need for a central authority at a high level of government (e.g. in the Office of the President, equivalent to the National Planning Commission) to coordinate and manage South Africa's ocean affairs, with the necessary legal powers to achieve the objectives outlined in the Green Paper process.

Finally, the Green Paper is physically confined to South African waters. It makes little mention of South Africa's role as a key player in the region whether it be the Southern African Development Community or the African Union. Be that as it may, the publication of the Green Paper is a vital step towards improved ocean governance and a significant opportunity for the marine scientific community to make a contribution. The timing of the publication of the Green Paper and accompanying notice inviting comment within 12 weeks was unfortunate in that it was published in the Government Gazette on the last day of October 2012. The deadline for comments to be submitted was stipulated as mid-January 2013. As the comment period straddled South Africa's traditional holiday period, the timing was most inconvenient, giving interested and affected parties, including civil society, very little time to provide substantial input. At the time of writing, the official date for submission of comments had been extended to mid-February 2013. An opportunity accordingly arose for the marine scientific community and other interested parties to provide an input to this important process.

\section{Acknowledgement}

The invaluable input, provided during a brainstorming session on the Green Paper held during December 2012, of Coleen Moloney, Jock Currie, Hayley Evers-King, Marieke van Zyl and Kate Watermeyer, staff and students of the Marine Research Institute, is acknowledged. 